\title{
Smoke-water Controls Pythium Damping-off in Papaya Seedling
}

\author{
Huey-Ling Lin ${ }^{1}$ \\ Department of Horticulture, National Chung Hsing University, 250 Kuokuang \\ Road, Taichung 402, Taiwan
}

Jenjira Chumpookam

Department of Horticulture, Faculty of Agriculture, Kasetsart University, Bangkok 10900, Thailand

Ching-Chang Shiesh

Department of Horticulture, National Chung Hsing University, 250 Kuokuang Road, Taichung 402, Taiwan

\section{Wen-Hsin Chung \\ Department of Plant Pathology, National Chung Hsing University, Taichung 402, Taiwan}

Additional index words. phenolic compounds, Carica papaya, morphology, scanning electron microscope (SEM)

\begin{abstract}
The antifungal efficacy of smoke-water on damping-off caused by Pythium sp. was evaluated both in vitro and in vivo. Smoke-water was generated by burning plant material and bubbling the smoke through water; its effect on the morphology of Pythium sp. was investigated by scanning electron microscope (SEM). Mycelia growth and oospore production of the fungus were significantly inhibited when cultured on water agar amended with smoke-water at $0 \%, 0.5 \%, 1 \%, 1.5 \%, 2 \%, 2.5 \%, 3 \%, 3.5 \%, 4 \%, 4.5 \%$, or $\mathbf{5 \%}$. In growth chamber experiments with potted seedlings growing in peatmoss, papaya plants treated with smoke-water exhibited reduced symptoms of damping-off when compared with control plants treated with water. Furthermore, the pots treated with $\mathbf{1 . 5 \%}$ or higher smoke-water did not show any symptoms of damping-off disease. Plant height significantly increased with treatment by higher concentrations of smoke-water. Maximum plant height was observed with treatment of $1 \%$ smoke-water or higher concentrations. One day after smoke-water application, SEM observations of the Pythium sp. revealed loss of structural integrity, abnormal degradation, deformation, abnormal lysis, cytoplasmic leakage, and hyphal slimming. This study showed that the addition of smoke-water to soil exerted significant disease suppression against Pythium sp., leading to improved growth of papaya seedlings.
\end{abstract}

Papaya is one of the most important tropical fruit crops with annual production of $\approx 9.1$ million tones and economic value of U.S. $\approx$ \$6097 million (FAOSTAT, 2012). Dampingoff is a major disease of papaya (Carica papaya L.) seedling in nurseries, glasshouses, gardens, fields, and forests (Agrios, 2005) and can be caused by several species of fungi, including Rhizoctonia solani, Pythium spp., Phytophthora spp., Sclerotinia spp., and Fusarium spp. (Stephens et al., 1982). These diseases are serious problems and have caused economic losses in commercial greenhouse seedling production.

\footnotetext{
Received for publication 7 May 2012. Accepted for publication 16 Aug. 2012.

We thank Professor Jenn-Wen Huang and Dr. Tsung-Chung Lin from the laboratory of plant disease management (National Chung Hsing University, Taiwan) for help in obtaining the pathogen isolates used in this work.

${ }^{1}$ To whom reprint requests should be addressed; e-mail hllin@dragon.nchu.edu.tw.
}

Damping-off disease caused by Pythium spp. usually begins as a root rot. Pythium survives in the soil as oospores that germinate and attack root hairs and root tips of seedlings, causing progressive deterioration of the root systems. The seed may fail to germinate because it rots in the ground or the seedling may wilt before aboveground lesions are evident (Franklin, 2001). Conditions for the development of this disease are high temperature, high humidity, high soil moisture, poor aeration, high levels of nitrogen fertilizer, and closely sown seed (Agrios, 2005).

Strategies to control and/or manage crop diseases effectively use a combination of cultural, biological, and chemical tools. Control of damping-off diseases is difficult. Dampingoff must be anticipated and prevented by using seed and transplant treatments before the seed or plants are put in the field (Franklin, 2001). Prevention practices include providing good soil drainage and good air circulation among plants, planting when temperatures are favorable for fast plant growth, avoiding application of excessive amounts of nitrate in nitrogen fertilizers, and practicing crop rotation (Agrios, 2005). Fungicides can currently be used but do present several problems. The use of fungicides has resulted in environmental pollution resulting from the accumulation of residual toxicity and has changed the profile of microorganisms in the soil (Muthukumar et al., 2010). Furthermore, the potential for undesired residues in the plant (Vanachter et al., 1983) and fungicide resistance in phytopathogenic fungi are limiting factors in using fungicides in crop protection (Brent, 1995). Resistance of the target pathogens to chemical a.i. curtails the efficacy and useful lifetime of fungicides, which must then be further developed at increasingly higher costs (Ma and Michailides, 2005).

Smoke-water, which is generated by burning plant material and bubbling the smoke through water, has been shown to enhance germination, improve growth, and promote the production of healthier plants (Light and Van Staden, 2004). It has the potential to be used in the horticultural and agricultural industries, particularly by farmers without the resources to purchase costly pesticides. Smoke-water contains a highly active compound, butenolide [3-methyl-2H-furo(2,3-c) pyran-2-one], derived from the burnt plant material (Van Staden et al., 2004) and cellulose. Butenolide has been shown to stimulate germination of lettuce at concentrations as low as $10^{-9} \mathrm{M}$ (Flematti et al., 2004) and to promote seed germination in many other species (Soos et al., 2009). In addition, smoke-water protects against microbial attack (De Groot, 1996). The phenolic compounds of smoke-water extract show antimicrobial activity that reduces the growth of microorganisms. Numerous studies have shown that phenolic compounds can inhibit the growth of soilborne pathogens (Muthukumar et al., 2010; Yangui et al., 2008).

To our knowledge, no studies have been reported on using smoke-water to manage the papaya seedling damping-off disease caused by Pythium sp. The objectives of this study were 1) to evaluate the antifungal properties of smoke-water in vitro and in vivo for efficacy against damping-off caused by a soilborne Pythium sp. isolated from papaya; and 2 ) to investigate the effect of smoke-water on the morphology of Pythium sp. using SEM observation.

\section{Materials and Methods}

Smoke-water production. A smoke-water solution was prepared by igniting $5 \mathrm{~kg}$ of dry rice straw (Oryza sativa L.) material in a $20-\mathrm{L}$ stainless steel barrel. Using compressed air, the smoke was continuously bubbled through a $500-\mathrm{mL}$ graduated cylinder filled with distilled water for $45 \mathrm{~min}$. Solutions of this aqueous smoke extract $(500 \mathrm{~mL})$ were filtered through Whatman No.1 filter paper and used as the stock solution. A similar method of preparing smoke-water with different plant material has been described by Boucher and Meets (2004). The apparatus for producing smoke-saturated water has been illustrated 
by De Lange and Boucher (1990) and Van Staden et al. (2004).

Seedling production. 'Tainung 2' papaya seeds were tested and found free of pathogens. Seeds were soaked with distilled water for $24 \mathrm{~h}$, surface-sterilized in $0.5 \% \mathrm{NaOCl}$ for $2 \mathrm{~min}$, and thoroughly rinsed for $1 \mathrm{~min}$ in three changes of sterile water. The seeds were sown in peatmoss (Tref, Australia) and grown in a greenhouse.

Plant pathogenic fungi and isolation. The Pythium sp. culture was originally isolated from papaya plants exhibiting symptoms of seedling damping-off disease. The roots were washed in running tap water, cut into pieces ( $1 \mathrm{~cm}$ long), rinsed three times in sterile distilled water, blotted dry with a paper towel, and then placed on $2 \%$ water agar. After $48 \mathrm{~h}$ incubation at $25{ }^{\circ} \mathrm{C}$, hyphal tips of fungi growing out from the collar region were cut and transferred onto potato dextrose agar (PDA, $200 \mathrm{~g}$ of potato, $20 \mathrm{~g}$ of dextrose, and $20 \mathrm{~g}$ of agar in $1 \mathrm{~L}$ ) and incubated at $25^{\circ} \mathrm{C}$. The isolate of Pythium sp. was observed under a light microscope and confirmed the morphology of Pythium sp. that could produce sporangia along somatic hyphae, form balloon-like vesicles, and produce zoospore and oospore. Moreover, the Pythium sp. could cause damping-off symptoms in papaya seedling after $3 \mathrm{~d}$ inoculated and reisolated from diseased tissue. The isolates were stored at $4{ }^{\circ} \mathrm{C}$ in petri dishes containing PDA medium.

Effect of smoke-water on oospore production of Pythium sp. Oospore production from isolates of Pythium sp. was initiated from 3-d-old cultures growing on V8 agar ( $100 \mathrm{~mL}$ of $\mathrm{V} 8$ juice, $2 \mathrm{~g}$ of $\mathrm{CaCO}_{3}$, and $20 \mathrm{~g}$ of agar in $1 \mathrm{~L}$ ) by punching $107-\mathrm{mm}$ diameter plugs from the colony margin with a sterile steel borer. These plugs were placed in beakers containing $20 \mathrm{~mL}$ of different concentrations of smoke-water $(0 \%, 0.5 \%$, $1 \%, 1.5 \%, 2 \%, 2.5 \%, 3 \%, 3.5 \%, 4 \%, 4.5 \%$, or $5 \%, \mathrm{v} / \mathrm{v})$. The beakers were incubated for $10 \mathrm{~h}$ at $25{ }^{\circ} \mathrm{C}$. Five $5-\mu \mathrm{L}$ drops from the oospore culture were placed on glass slides and viewed under a light microscope at $20 \times$ magnification to estimate the number of oospores by a mechanical counter.

Effect of smoke-water on mycelial growth of Pythium sp. To study the effectiveness of smoke-water against mycelial growth of Pythium sp., different smoke treatments $(0.5 \%$, $1 \%, 1.5 \%, 2 \%, 2.5 \%, 3 \%, 3.5 \%, 4 \% 4.5 \%$, or $5 \%, \mathrm{v} / \mathrm{v}$ ) were prepared by mixing smokewater into the water agar medium once it had cooled to $\approx 45{ }^{\circ} \mathrm{C}$. After mixing, the smokewater agar mixture was dispensed into $9-\mathrm{cm}$ diameter petri dishes and allowed to cool. Four-millimeter diameter plugs of agar from young, pure cultures of Pythium sp. were placed on the surface of the smoke-water agar medium mycelium side down. The plates were incubated at $25{ }^{\circ} \mathrm{C}$, and the radial growth of mycelial was measured at 12-h intervals for a week. Water agar without the addition of smoke-water was also inoculated with Pythium sp. and was used as the control. Five replicates of each concentration were used and experiments were repeated twice.
Scanning electron microscope observations. For preparation of SEM samples, a small plug (4-mm diameter) of mycelia was taken from the margin and placed on the water agar plates and then the plates were incubated at $25^{\circ} \mathrm{C}$ for $3 \mathrm{~d}$. Before sampling, the growing mycelial was sprayed with $1 \mathrm{~mL}$ $3 \%$ smoke-water per plate and incubated at $25{ }^{\circ} \mathrm{C}$ for $1 \mathrm{~d}$. The samples were frozen with liquid nitrogen and then transferred into the vacuum chamber (CryoTrans System; Model E7400; BioRad, U.K.) for coating with gold. The samples coated with gold were transferred into SEM (ABT-150S; TOPCON, Japan) and observed under $15 \mathrm{kV}$.

Pot experiment peatmoss preparation. The Tref peatmoss (Australia; $\mathrm{pH}$ : 5.5, electrical conductivity: $2.5 \mathrm{mS} \cdot \mathrm{cm}^{-1}$, organic matter content: $85 \%$, total nitrogen: $160 \mu \mathrm{g} \cdot \mathrm{g}^{-1}$, phosphorus: $78.66 \mu \mathrm{g} \cdot \mathrm{g}^{-1}$, potassium: $166 \mu \mathrm{g} \cdot \mathrm{g}^{-1}$, and magnesium: $80 \mu \mathrm{g} \cdot \mathrm{g}^{-1}$ ) was moistened with distilled water to $60 \%$ of its waterholding capacity and autoclaved at $121^{\circ} \mathrm{C}$.

Peatmoss inoculation. Oospore suspension of Pythium sp. was initiated with 10 7-mm plugs from 3-d-old V8 agar cultures in beakers containing $20 \mathrm{~mL}$ of distilled water. The cultures were incubated for $10 \mathrm{~h}$ at $25^{\circ} \mathrm{C}$ and diluted serially to obtain $10^{-5}$ spores $/ \mathrm{mL}$. One kilogram of autoclaved peatmoss was inoculated with $10 \mathrm{~mL}$ of the diluted oospore suspension. Seven days after inoculation, $20 \mathrm{~mL}$ of smoke-water in a range of concentrations $(0.5 \%, 1 \%, 1.5 \%, 2 \%, 2.5 \%$, $3 \%, 3.5 \%, 4 \%, 4.5 \%$, or $5 \%, \mathrm{v} / \mathrm{v}$ ) was added to the inoculated soil samples. Seven days

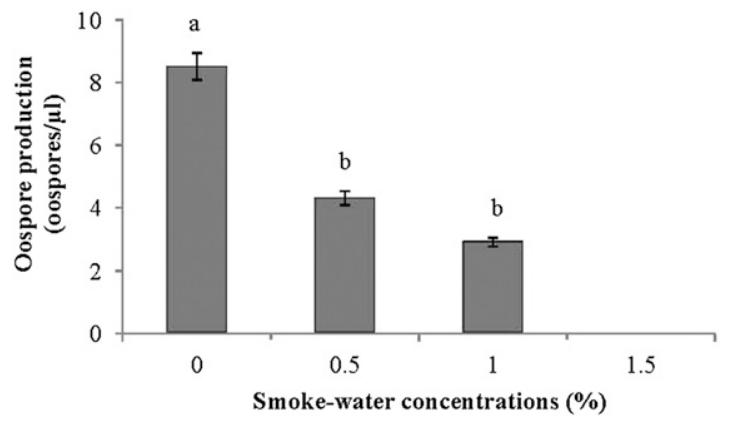

Fig. 1. The effect of smoke-water concentrations on oospore production of Pythium sp. The results represent mean $\pm \mathrm{SE}$.

Table 1. The effect of smoke-water concentrations on mycelial growth of Pythium sp.

\begin{tabular}{ccccc}
\hline & \multicolumn{3}{c}{ Mycelial growth $(\mathrm{mm})$} & \\
\cline { 2 - 4 } Smoke-water & $12 \mathrm{~h}$ & $24 \mathrm{~h}$ & $36 \mathrm{~h}$ & Growth rate $\left(\mathrm{mm} \cdot \mathrm{h}^{-1}\right)$ \\
\hline $0 \%$ & $14.24 \mathrm{a}^{\mathrm{z}}$ & $40.85 \mathrm{a}$ & $69.13 \mathrm{a}$ & $2.29 \mathrm{a}$ \\
$0.5 \%$ & $8.88 \mathrm{~b}$ & $32.64 \mathrm{~b}$ & $55.34 \mathrm{~b}$ & $1.93 \mathrm{~b}$ \\
$1.0 \%$ & $5.26 \mathrm{c}$ & $21.30 \mathrm{c}$ & $36.40 \mathrm{c}$ & $1.30 \mathrm{c}$ \\
$1.5 \%$ & $2.69 \mathrm{~d}$ & $15.76 \mathrm{~d}$ & $23.26 \mathrm{~d}$ & $0.86 \mathrm{~d}$ \\
$2.0 \%$ & $2.05 \mathrm{e}$ & $11.22 \mathrm{e}$ & $16.53 \mathrm{e}$ & $0.60 \mathrm{e}$ \\
$2.5 \%$ & $0.63 \mathrm{f}$ & $5.09 \mathrm{f}$ & $12.27 \mathrm{f}$ & $0.49 \mathrm{f}$ \\
$3.0 \%$ & $0.00 \mathrm{~g}$ & $1.07 \mathrm{~g}$ & $2.93 \mathrm{~g}$ & $0.16 \mathrm{~g}$ \\
$3.5 \%$ & $0.00 \mathrm{~g}$ & $0.00 \mathrm{~h}$ & $0.00 \mathrm{~h}$ & $0.00 \mathrm{~h}$ \\
$4.0 \%$ & $0.00 \mathrm{~g}$ & $0.00 \mathrm{~h}$ & $0.00 \mathrm{~h}$ & $0.00 \mathrm{~h}$ \\
$4.5 \%$ & $0.00 \mathrm{~g}$ & $0.00 \mathrm{~h}$ & $0.00 \mathrm{~h}$ & $0.00 \mathrm{~h}$ \\
$5.0 \%$ & $0.00 \mathrm{~g}$ & $0.00 \mathrm{~h}$ & $0.00 \mathrm{~h}$ & $0.00 \mathrm{~h}$ \\
\hline
\end{tabular}

${ }^{\mathrm{z}}$ Values in each column with the same letter are not significantly different at the $1 \%$ level of significance. after the addition of the various smoke-water concentrations, the peatmoss was placed in plastic pots $(10 \mathrm{~cm} \times 8.5 \mathrm{~cm} \times 7 \mathrm{~cm}, 200 \mathrm{~g}$ of peatmoss per pot). Papaya seedlings with two true leaves were transplanted (four plants/pot) into four pots for each smoke-water concenthe replications for each concentration. Pots were placed in a growth chamber and maintained for a growing period of 4 weeks at $8 \mathrm{~h}$ light at $30^{\circ} \mathrm{C}$ and $16 \mathrm{~h}$ dark at $25^{\circ} \mathrm{C}$ with constant relative humidity at $75 \%$. rradiance was provided at $400 \mu \mathrm{mol} \cdot \mathrm{m}^{-2} \cdot \mathrm{s}^{-1}$ using daylight fluorescent lamps. Plant disease incidence was expressed as the percentage of the number of plants showing typical symptoms caused by Pythium sp. There were two controls: one for non-infected soil and another for soil infected with Pythium sp. but ot treated with smoke-water. data were analyzed using SAS 9.2 software (SAS Institute, 2002) and subjected to oneway analysis of variance by a completely randomized design statistical model. Mean values among treatments, when significant, 作 significance.

In vitro effect of smoke-water on Pythium $\mathrm{sp}$. All concentrations of smoke-water significantly reduced the production of Pythium oospores (Fig. 1). A complete inhibition of oospores production was observed when the
Statistical analysis. The experimental ence tests at the $1 \%(P \leq$ 
smoke-water concentration was greater than $1.5 \%(\mathrm{v} / \mathrm{v})$

Using water agar containing a range of smoke-water concentrations, inhibition of mycelia growth of Pythium sp. was evaluated (Table 1). In all smoke-water treatments, both the mycelia growth and the rate of growth between 12 and $36 \mathrm{~h}$ were significantly reduced compared with the control. High concentrations of smoke-water from $3.5 \%$ to $5 \%$ were efficient in preventing all mycelium growth.

Scanning electron microscope observations. Scanning electron microscope observations (Fig. 2) revealed that application of $3 \%$ smoke-water caused loss of structural integrity, abnormal degradation, deformation, abnormal lysis, cytoplasmic leakage, and hyphal slimming of Pythium sp. mycelia.

Suppression of Pythium damping-off disease by smoke-water in vivo. The ability of smoke-water to suppress damping-off disease in soil-grown plants was tested (Table 2; Fig. 3). The percentage of papaya seedlings with damping-off disease was significantly reduced by all concentrations of smokewater. The critical concentration of smokewater seems to be between $0.5 \%$ and $1 \%(\mathrm{v} / \mathrm{v})$, because the percentage damping-off disease reduced dramatically, from $18.75 \%$ to $2.08 \%$, at these two concentrations. In contrast, $68.75 \%$ of the control (infected soil, $0 \%$ smoke-water) papaya seedlings showed symptoms of damping-off. Effective concentrations of smoke-water reduced all types of symptoms of damping-off disease on papaya seedlings, including plant underdevelopment, lesions on roots and stems, collapse of seedling stems near ground level, yellowing of leaves, and plant wilt. The root system showed death of the lateral roots and rotting of root tissues below the soil surface.

The application of smoke-water at $1 \%(\mathrm{v} / \mathrm{v})$ or higher significantly increased the height of the papaya seedlings $(12.53 \mathrm{~cm}$ at $1 \%)$ compared with the infected soil control $(9.97 \mathrm{~cm}$ at $0 \%$ ). Smoke-water treatments were not significantly different from the non-infected soil control $(12.84 \mathrm{~cm})$

\section{Discussion}

Incorporation of smoke-water into water agar medium inhibited growth of Pythium sp. with a complete inhibition of mycelium growth observed for smoke-water concentrations of $3.5 \%(\mathrm{v} / \mathrm{v})$ and higher. Furthermore, oospore production was completely inhibited at and above $1.5 \%(\mathrm{v} / \mathrm{v})$ smoke-water in liquid cultures. The complete inhibition of both mycelia growth and oospores production of Pythium sp. demonstrated this promising and potential antifungal activity of a simple smoke-water solution. The fungal inhibition could be attributable directly to the acid $\mathrm{pH}$ of smoke-water and the chelating of transition metals by phenolic compounds (Chumpookam et al., 2012).

Paraskeva and Diamadopoulos (2006) reported that phenolic compounds can be either simple phenols and flavonoids or polyphenols, which result from polymerization of the simple phenols and are toxic to microorganisms. Wong and Kitts (2006) found that phenolic compounds are able to chelate transition metals and lower the reactivity of metal iron by forming an inert metal-ligand complex. Phenolic compounds are building blocks for cell wall structures and defend against pathogens (Hahlbrock and Scheel, 1989) by altering the pathogen cell wall and its ability to react with proteins through protein crosslinking and protein denaturing (Ciafardini and Zullo, 2003).

The presence of the antifungal compound 1-methyl-4-nitroso-5-phenyl-1H-imidazole in the smoke-water extract (Chumpookam et al., 2012) may also contribute to the inhibition of Pythium sp. growth. Imidazoles are a group of drugs that are active against fungi and are also effective against a wide range of bacteria. Some imidazole drugs have the ability to
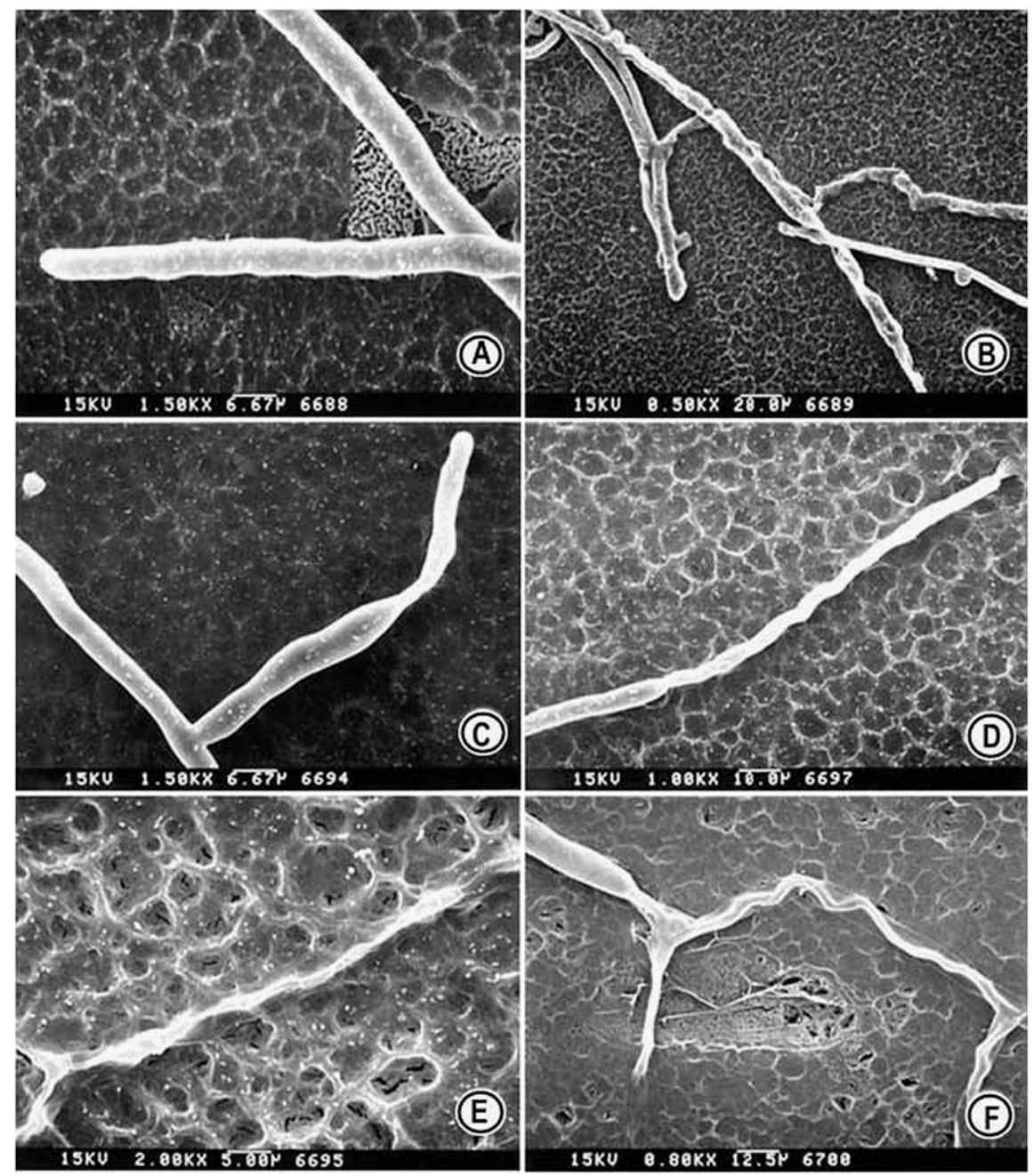

Fig. 2. The effect of spray application of 3\% smoke-water on the morphology of Pythium sp. in scanning electron microscopy observation: (A) normal mycelia (control); (B) abnormal degradation; (C-D) deformation; (E) abnormal lysis; and (F) cytoplasmic leakage and further hyphal slimming.

Table 2. The effect of smoke-water on the prevalence of damping-off disease on papaya grown in peatmoss in plastic pots.

\begin{tabular}{lcc}
\hline Smoke-water concn & $\begin{array}{r}\text { Percentage of papaya seedlings } \\
\text { with damping-off disease }(\%)\end{array}$ & Plant ht (cm) \\
\hline Control (non-infected soil) & $0.00 \mathrm{c}^{\mathrm{z}}$ & $12.84 \mathrm{a}$ \\
$0.0 \%$ (infected soil) & $68.75 \mathrm{a}$ & $9.97 \mathrm{c}$ \\
$0.5 \%$ & $18.75 \mathrm{~b}$ & $11.54 \mathrm{~b}$ \\
$1.0 \%$ & $2.08 \mathrm{c}$ & $12.53 \mathrm{ab}$ \\
$1.5 \%$ & $0.00 \mathrm{c}$ & $12.99 \mathrm{a}$ \\
$2.0 \%$ & $0.00 \mathrm{c}$ & $12.72 \mathrm{ab}$ \\
$2.5 \%$ & $0.00 \mathrm{c}$ & $12.74 \mathrm{ab}$ \\
$3.0 \%$ & $0.00 \mathrm{c}$ & $12.95 \mathrm{a}$ \\
$3.5 \%$ & $0.00 \mathrm{c}$ & $13.25 \mathrm{a}$ \\
$4.0 \%$ & $0.00 \mathrm{c}$ & $12.77 \mathrm{ab}$ \\
$4.5 \%$ & $0.00 \mathrm{c}$ & $13.17 \mathrm{a}$ \\
$5.0 \%$ & $0.00 \mathrm{c}$ & $12.36 \mathrm{ab}$ \\
\hline
\end{tabular}

${ }^{\mathrm{z}}$ Values in each column with the same letter are not significantly different at the $1 \%$ level of significance. 

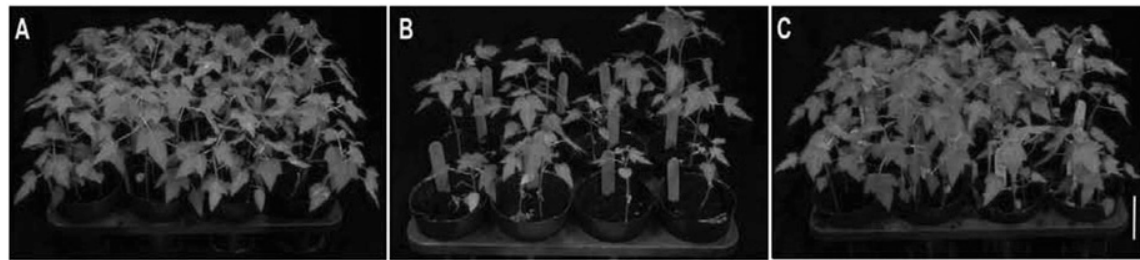

Fig. 3. The appearance of 'TN-2' seedlings were grown in non-infected peamoss (A), in Pythium sp.infected peatmoss (B), or in Pythium sp.-infected peatmoss and 0.5\% smoke-water (C) for 4 weeks. Scale bar: $70 \mathrm{~mm}$

damage membranes when used at a high concentration for a short time independently of the culture medium and growth rate. When in contact with cell wall of fungi, imidazoles interact directly with the double lipid layer of the membrane structure, presumably by binding to the unsaturated fatty acid part of the phospholipid components of the membrane (Jain et al., 2010). This inhibition leads to diminished levels of sterol in the fungal cell membrane as well as an accumulation of toxic ergosterol intermediates, which may play a key role in the killing of the fungal cell (Sanglard et al., 1996). It is likely that the phenolic and imidazole compounds in smokewater work in concert to inhibit the growth of Pythium sp. and thus prevent Pythium damping-off disease in this study.

Several apparent mechanisms or antifungal compounds involved in the antagonism of pathogenic fungi have been previously proposed. They include interference with spore germination or germ tube elongation inhibition through abnormal hyphal swelling (Jung et al., 2003), lysis and complete degradation of the hyphae (Wang et al., 1999).

Other researchers have demonstrated that smoke-water can protect the seeds and seedlings of many plant species in the southwest of Western Australia against microbial attack, resulting in higher seedling survival and healthier seedlings for transplanting (Roche et al., 1997). A greater percentage of healthy seedlings would be an asset to commercial transplant production (Bennett et al., 1992).

\section{Conclusions}

The present study confirmed the usefulness of smoke-water in controlling dampingoff caused by the soilborne fungi Pythium sp. Our rice straw-derived smoke-water compound has an antifungal activity against Pythium sp., which may be the result of the presence of phenolic and imidazole compounds that have been shown to inhibit ergosterol biosynthesis in fungi cells, which plays a role in the killing of the fungal cell. This study validates that the addition of smoke-water to soil in the nursery significantly suppresses Pythium damping-off disease and improves the growth of papaya seedlings.

\section{Literature Cited}

Agrios, G.N. 2005. Plant pathology. 5th Ed. Elsevier Academic Press, San Diego, CA.

Bennett, M.A., V.A. Fritz, and N.W. Callan. 1992 Impact of seed treatments on crop stand establishment. HortTechnology 2:345-349.

Boucher, C. and M. Meets. 2004. Determination of the relative activity of aqueous plant-derived smoke solutions used in seed germination. S. Afr. J. Bot. 70:313-318.

Brent, K.J. 1995. Fungicide resistance in crop pathogens: How can it be managed? J. Global Crop Protection Federation, Brussels, Belgium.

Chumpookam, J., H.L. Lin, C.C. Shiesh, and K.L. Ku. 2012. Effect of smoke-water on seed germination and resistance to Rhizoctonia Solani inciting papaya damping-off. Horticulture NCHU. 37:13-29.

Ciafardini, G. and B.A. Zullo. 2003. Antibacterial activity of oil-mill waste water polyphenols on the phytopathogen Xanthomonas campestris spp. Ann. Microbiol. 53:283-290.

De Groot, I. 1996. Protection of stored grains and pulses. 3rd Ed. Agromisa Foundation, Agr. Univ. Wageningen, Wageningen, The Netherlands.

De Lange, J.H. and C. Boucher. 1990. Autecological studies on Audouinia capitata (Bruniaceae). I. Plant-derived smoke as a seed germination cue. S. Afr. J. Bot. 56:700-703.

FAOSTAT. 2012. FAO statistical yearbook 2012.

Flematti, G.R., E.L. Ghisalberti, K.W. Dixon, and R.D. Trengove. 2004. A compound from smoke that promotes seed germination. Science 305: 977.

Franklin, L. 2001. Damping-off disease. University of California, Oakland, CA

Hahlbrock, K. and D. Scheel. 1989. Physiology and molecular biology of phenylpropanoid metabolism. Annu. Rev. Plant Physiol. Plant Mol. Biol. 40:347-369.

Jain, A.K., V. Ravichandran, M. Sisodiyal, and R.K. Agrawal. 2010. Synthesis and antibacterial evaluation of 2-substituted-4,5-diphenyl-N-alkyl imidazole derivatives. Asian Pac. J. Trop. Med. $3: 471-474$

Jung, J.W., K.N. An, Y.L. Jin, R.D. Park, K.T. Lim, K.Y. Kim, and T.H. Kim. 2003. Biological control of damping-off caused by Rhizoctonia Solani using chitinase-producing Paenibacilus illinoisensis KJA-424. Soil Biol. Biochem. 35:1261-1264.

Light, M.E. and J. Van Staden. 2004. The potential of smoke in seed technology. S. Afr. J. Bot. 70:97-101.

Ma, Z. and T.J. Michailides. 2005. Advances in understanding molecular mechanisms of fungicide resistance and molecular detection of resistant genotypes in phytopathogenic fungi. Crop Prot. 24:853-863.

Muthukumar, A., A. Eswaran, S. Nakkeeran, and G. Sangeetha. 2010. Efficacy of plant extracts and biocontrol agents against Pythium aphanidermatum inciting chilli damping-off. Crop Prot. 29:1483-1488.

Paraskeva, P. and E. Diamadopoulos. 2006. Review technologies for olive mill waste water (OMW) treatment: A review. J. Chem. Technol. Biotechnol. 81:1475-1485.

Roche, S., J.M. Koch, and K.W. Dixon. 1997. Smoke enhanced seed germination for mine rehabilitation in the southwest of Western Australia. Restor. Ecol. 5:191-203.

Sanglard, D., F. Ischer, M. Monod, and J. Bille. 1996. Antimicrob agents. Chemothera 40:2300.

SAS Institute. 2002. SAS for Windows, version 9.2. SAS Institute, Inc., Cary, NC.

Soos, V., A. Juhasz, M.E. Light, J. Van Staden, and E. Balazs. 2009. Smoke-water-induced changes of expression pattern in grand rapids lettuce achenes. Seed Sci. Res. 19:37-49.

Stephens, C.T., L.J. Herr, and A.F. Schmitthenner. 1982. Characterization of Rhizoctonia isolates associated with damping-off of bedding plants. Plant Dis. 66:700-703.

Van Staden, J., A.K. Jäger, M.E. Light, and B.V. Burger. 2004. Isolation of the major germination cue from plant-derived smoke. S. Afr. J. Bot. 70:654-659.

Vanachter, A., E. van Wembeke, and C. van Assche. 1983. Potential danger for infection and spread of root disease of tomatoes in hydroponics. Acta Hort. 133:119-127.

Wang, S.L., T.C. Yieh, and I.L. Shih. 1999. Production of antifungal compounds by Pseudomonas aeruginisa $\mathrm{K}-187$ using shrimp and crab shell powder as a carbon source. Enzyme Microb. Technol. 25:142-148.

Wong, P.Y.Y. and D.D. Kitts. 2006. Studies on the dual antioxidant and antibacterial properties of parsley (Petroselinum crispum) and cilantro (Coriandrum sativum) extracts. J. Food Chem. 97:505-515.

Yangui, T., A. Rhouma, M.A. Triki, K. Gargouri, and J. Bouzid. 2008. Control of damping-off caused by by Rhizoctonia solani and Fusarium solani using olive mill waste water and some of its indigenous bacterial strains. Crop Prot. 27:189-197. 